\title{
Die implikasies van 'n konsekwent probleem-historiese metode van wysgerige historiografie vir geslagtelike verskille en verhoudings
}

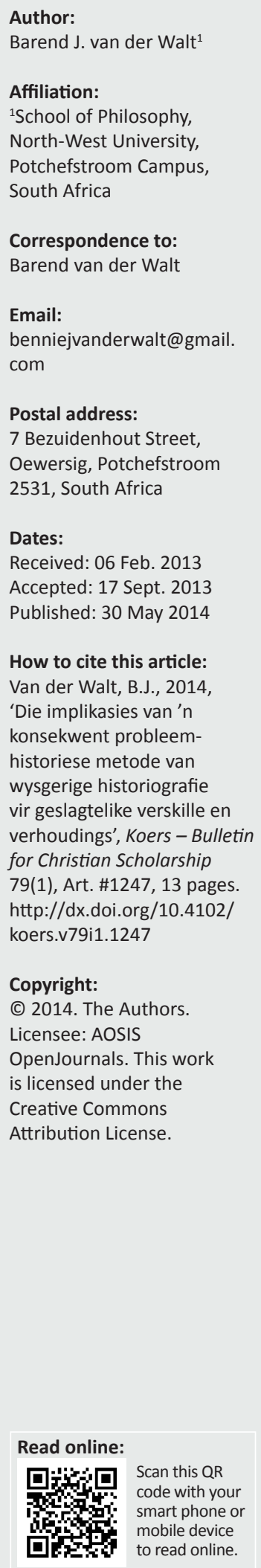

Hierdie ondersoek verken die moontlike implikasies van Dirk H.Th. Vollenhoven (18921978) se konsekwent probleem-historiese metode met die oog op groter duidelikheid oor die vraagstuk van menslike geslagtelikheid en die onderlinge verhouding tussen die twee geslagte. Dit toon ook terloops aan hoe die resultate van hierdie Christelike filosoof se noukeurige analise van Westerse werklikheids- en mensvisies belangrike leemtes in die baanbrekende navorsing van suster Prudence Allen kan vul. Allen se navorsing is in ' $n$ voorafgaande artikel in hierdie tydskrif bespreek. Eers word Vollenhoven se siening ten opsigte van die onderskeid en die verband tussen God, sy wet en die kosmos verduidelik. 'n Volgende afdeling bespreek dan die hoofkontoere van sy wysgerige historiografie, naamlik sy indeling van die filosofiegeskiedenis in drie hooftydperke (voorsintese, sintese en antisintese), 'n verskeidenheid normatiewe stromings en drie basiese kosmologiese probleme (konstantheid versus verandering, eenheid versus verskeidenheid en die universele versus die individuele). In 'n derde onderdeel word uit 'n seleksie van die groot aantal mensvisies nagegaan wat hulle moontlike implikasies vir die vraagstuk van geslagtelikheid kan wees. Ten slotte word 'n ondersoek geloods na Vollenhoven se eie mensvisie om te probeer vasstel waarom hy, ten spyte van sy diepgaande blootlegging van die ontiese en antropologiese grondslae van die Westerse denke, hom nie meer eksplisiet oor die implikasies daarvan vir menslike geslagtelikheid uitgespreek het nie.

The implications of a consistent problem-historical method of philosophical historiography for gender distinctions and relations. Reconnoitring the possible implications of the consistent problem-historical method of Dirk H.Th. Vollenhoven (1892-1978) to attain more clarity on the issue of gender and gender relations is the main aim of this investigation. In passing, it also indicates how the results obtained by this Christian philosopher's careful analysis of Western ontologies and anthropologies may alleviate the deficiencies in the otherwise groundbreaking study of sister Prudence Allen. Allen's study was discussed in a previous article in this journal. The introductory section explains how Vollenhoven himself viewed the difference and relation between God, his laws and his creation. The next section discusses the main contours of his historiography of philosophy, viz. his division of the history of philosophy intothree main periods (pre-synthetic, synthetic and anti-synthetic), a diversity of normative time-currents and three basic cosmological problems (consistency versus change, unity versus diversity and universal versus individual). From the great number of anthropologies, the third section selects a few examples to illustrate their possible implications for the problems related to sexuality and gender. The conclusion tries to pinpoint Vollenhoven's own anthropology in order to ascertain why he, in spite of his thorough and profound exposure of the ontological and anthropological foundations of Western thinking, did not more explicitly express himself about their implications for gender issues.

\section{Ter inleiding}

Vooraf is enkele verduidelikings nodig. In die eerste plek oor die blywende aktualiteit van die ondersoek. Tweedens ' $n$ herinnering aan die verdienstes en gebreke in die werk van 'n feministiese filosoof (Allen 1985), wat in 'n vorige artikel in hierdie tydskrif bespreek is. Om die leemtes in haar werk aan te vul, sal derdens, uit die sterk punte van 'n ander filosofiese historiograaf, Vollenhoven, meer duidelikheid gesoek word oor die antropologiese grondslae van die probleme rondom manlike en vroulike geslagtelikheid.

\section{Blywende aktualiteit}

Animals are simply animals, stones are stones and trees are trees. They do not ask: Who am I? Only man cannot escape himself. We are constantly moved to reflect upon ourselves. We are our own greatest puzzle ... we ask ourselves: What does it mean to be human or inhuman? (Olthuis \& DeGraaff 1978:1) 
Daar bestaan groot eenstemmigheid dat hierdie vraag en die antwoord daarop van wesenlike belang is. Hoe die mens beskou word, bepaal immers die lewenspraktyk, naamlik hoe jy met die aarde omgaan, hoe jy jou kinders grootmaak, 'n nasie regeer, hoe jy liggaamlike en emosionele siektes behandel, godsdiens beoefen en nog baie meer. Mensvisies beïnvloed die werk van opvoedkundiges, sosiale werkers, psigoterapeute en predikante en dit bepaal ook 'n mens se visie op die manlike en vroulike geslag en hulle onderlinge verhoudings.

Die meeste mense stem saam dat vrae soos 'wie is ek?' en 'wat behoort ek te doen?' van die allergrootste belang is, hoewel daar tog geen algemeen aanvaarbare antwoord daarop is nie - eerder talle en selfs botsende beskouings.

Hierdie verkenning bied vanselfsprekend nie eers naastenby 'n oorsig oor die groot verskeidenheid visies op die mens nie (vgl. Van der Walt 2014b). Dit wil slegs met enkele voorbeelde aantoon hoe persone se filosofiese visie op die homo sapiens ook implikasies inhou vir hulle visie op manlike en vroulike geslagtelikheid. Daarmee word 'n aanvulling gebied op 'n voorafgaande artikel. Daarin is 'n vroulike filosoof, suster Prudence Allen (1985) se gedagtes oor geslagtelikheid bespreek. In die huidige artikel stel die outeur hom in die skoene van 'n manlike wysgeer, Dirk H.Th. Vollenhoven (1892-1978), om te probeer aantoon watter implikasies sy analise van Westerse antropologieë vir 'n mens se visie op geslagtelikheid het.

Om die geheue te verfris en die pad vorentoe te verken, word vervolgens vlugtig enkele sterk en swak punte van hierdie twee denkers ('n Katoliek en 'n Calvinis) oor die onderwerp genoem.

\section{Verdienstes en gebreke by Allen}

Deeglike filosofiese werke oor menslike geslagtelikheid is nie volop nie - veral geskrifte wat uit primêre bronne ideehistories 'n oorsig bied van meer as 2000 jaar se geskiedenis aangaande die begrippe vrou en man en hulle moontlike onderlinge verhouding. Bowendien betrek Allen in haar ondersoek nie net manlike nie, maar ook vroulike outeurs. Aan hierdie boeiende en baanbrekende studie het 'n vorige artikel (vgl. Van der Walt 2014a) reeds aandag gegee. Hier word dus slegs enkele tekortkomings genoem waarvoor Vollenhoven se filosofiese historiografie moontlik 'n oplossing kan bied.

In die eerste plek is Allen se filosofiese vertrekpunt 'n struikelblok, naamlik 'n basiese onderskeid tussen natuur en genade. Daarvolgens moet sy God en sy openbaring (as bonatuurlik beskou) uit haar filosofiese historiografie (op die sg. natuurlike terrein) uitsluit. Filosofie mag volgens haar geen beroep op geloof maak nie, maar slegs met redelike middele die aardse werklikheid bestudeer. Vir haar is 'n Christelike filosofie dus 'n onmoontlikheid.

Indien God as Skepper uitgesluit word uit 'n mens se filosofie, is die vraag of ' $n$ mens werklik sy skepping (man en vrou ingesluit) kan verstaan. Sluit jy bowendien God as Wetgewer uit, moet sy verordenings (ook vir die verhouding tussen die twee geslagte) in die skepping self gesoek word. Dit lei tot die volgende twee leemtes by Allen.

Dit is nie net 'n geval dat haar eie mensbeskouing nie duidelik uit die verf kom nie. Sy beskik ook nie oor die nodige ontiese en antropologiese kategorieë om duidelik te kan maak waarom daar verskillende visies op die twee geslagte bestaan het nie. Heel waarskynlik sit sy nog gevange in 'n tipe antropologie waarin sy van 'n hoër-laer onderskeid (bv. tussen siel en liggaam) uitgaan en probeer sy om eenheid tussen die twee veronderstelde komponente van menswees te bedink.

Om dieselfde rede weifel sy soms om te besluit of 'n bepaalde denker 'n eenheids-, polariteits- of komplementariteitsvisie gehuldig het. Haar tipologie van slegs drie hooftipes - uit 'n baie groot verskeidenheid mensvisies in die loop van die geskiedenis - word veels te maklik aan 'n spesifieke denker toegeskryf.

Verder soek Allen tevergeefs na 'n normatiewe riglyn vir man- en vrouwees en hulle verhouding, omdat sy - in plaas van daarbuite, sodat dit werklike geldingskrag kan hê - dit (subjektivisties) in 'n bepaalde verhouding (dié van komplementariteit) soek.

\section{Gebreke en verdienstes by Vollenhoven}

Vollenhoven se bedoeling met sy konsekwent probleemhistoriese historiografie was volgens Tol, een van die beste kenners van Vollenhoven, 'to make visible the lay-out of basic problems of thought through the whole history of Western philosophy' (Tol 2013). Let daarop dat dit vir hom nie gegaan het oor slegs een probleem soos in die geval van Allen nie, maar oor die ontologiese en antropologiese grondprobleme van die filosofie. (Vgl. Vollenhoven 2011:45 vir dit wat hy as grondprobleme beskou het.) Vir Vollenhoven was 'n denker se visie op geslagtelikheid egter blykbaar nie so 'n grondprobleem nie.

Storkey $(1995: 85,86)$ merk op dat ook Herman Dooyeweerd (1894-1977) geen denker se visie op die vrou bespreek nie en dat daar ook geen fokus op die vroulike dimensie in sy eie antropologie is nie. Hierdie uitspraak sou tot' $n$ groot mate net so van sy tyd- en geesgenoot Vollenhoven kon geld. Hoewel Vollenhoven (2000) nie soveel vroulike denkers soos Allen (1985) in sy werk behandel nie, is daarin nogtans tiperings van die denke van die volgende vier belangrike vrouefigure te vind, naamlik Hypatia, Teresa van Avila, Edith Stein en Simone Weil.

Gedurende die verdere ontwikkeling van die reformatoriese filosofie aan die Vrije Universiteit van Amsterdam is hierdie leemte nog duideliker raakgesien en het dit meer aandag begin ontvang (vgl. Woldring 2013:288-289, 366-369). Seerveld (2014) bied byvoorbeeld 'n histories-sistematiese oorsig oor die geskiedenis van die nadenke oor die onderdrukte 
vroulike geslag. Ten spyte van die genoemde opmerkings oor 'n belangrike leemte by Dooyeweerd en Vollenhoven, vind Storkey tog dat sekere van hulle filosofiese insigte (bv. die modaliteitsleer) ' $n$ waardevolle bydrae kan bied om onder andere die verskil tussen seksualiteit (die biologiese) en geslagtelikheid (die bo-biologiese aspekte van menswees) duidelik te maak.

Hierdie artikel wil aantoon dat, al het Vollenhoven nie eksplisiet oor seksualiteit en geslagtelikheid gepubliseer nie, sy grondleggende onties-antropologiese ondersoek van die geskiedenis van die filosofie implisiet 'n onontginde goudmyn is. Hierdie artikel wil dit sover moontlik na die oppervlak bring.

\section{Fokus, aanpak en opset}

Met hierdie doel voor oë is dit nodig om weens die relatiewe onbekendheid daarvan, eerstens Vollenhoven se historiografiese metode kortliks te verduidelik; tweedens, die moontlike implikasies vir die kwessie van geslagtelikheid daaruit af te lei; en derdens, om deurentyd die leser daaraan te herinner hoe Vollenhoven se aanpak 'n aansienlike verbetering bied bó dié van Allen. Om die artikel vir 'n breëre leserspubliek toeganklik te maak, sal die uiteensetting van Vollenhoven se ingewikkelde benadering so eenvoudig moontlik weergegee word en die fyner detail vermy word om slegs tot die hooftrekke daarvan beperk te wees. (Geïnteresseerde lesers kan vir verstaanbare verduidelikings van sy metode byvoorbeeld Bril [1986, 2005]; Tol \& Bril [1992] asook Kok [1998:1-178] raadpleeg. Vir Afrikaanssprekende lesers kan Van der Walt [2013a, 2013b] van hulp wees. Laasgenoemde artikel bevat ook verskillende punte van kritiek wat reeds op Vollenhoven se metode gelewer is.)

Agtereenvolgens word nou aandag geskenk aan Vollenhoven se tweesydige metode; sy eie ontologie; drie hoofonderskeidings in sy historiografie (hoofperiodes, stromings en tipes filosofie); drie belangrike ontiese vertrekpunte; die groot verskeidenheid mensvisies wat hy onderskei en ten slotte, Vollenhoven se eie visie op die mens en geslagtelikheid.

\section{Vollenhoven se tweesydige metode van filosofeer en sy eie ontologie}

Baie mense, Christene ingesluit, probeer hulle eie standpunt duidelik maak deur (negatief) te sê waarmee hulle nie saamstem nie. Om 'n Christelike filosofie te beoefen sou dan inhou dat so 'n persoon sou sê met watter beskouing nie saamgestem word nie. Daardeur word 'n mens se eie standpunt egter (negatief) afhanklik gemaak van dit wat die persoon juis bestry.

\section{Vollenhoven se alternatief van 'n tweesydige benadering}

Vollenhoven verkies tereg om nie bloot antiteties te dink nie, maar met ' $n$ tetiese standpuntinname te begin.

\section{Eers teties}

Geen filosofiese kennis is moontlik sonder 'n verantwoording oor'n mens se eie standpunt nie. Vanuit 'n eie positiewe visienie bloot antiteties-negatief nie-moet'n denker die filosofiese probleme konfronteer wat die geskiedenis opgelewer het. Vollenhoven bied sy eie vertrekpunte of sistematiese filosofie in Vollenhoven (2005a) en die tekskritiese uitgawe daarvan onder redaksie van Tol (Vollenhoven 2010). Hoe sy eie metode en standpunt geleidelik ontwikkel het, word deur Tol (2010, 2011) beskryf.

\section{Tweedens krities}

'n Vooringenome tetiese visie impliseer egter nie finale antwoorde op alle probleme nie - by die tetiese moet ook 'n kritiese element bykom. Dit hou onder meer in dat ook andersdenkendes se filosofieë noukeurig bestudeer, ondervra en geëvalueer word ten opsigte van sowel die verdienstes as die gebreke en foute daarin. Terselfdertyd is dit ook nodig om daardeur blinde kolle en leemtes in jou eie tetiese vertrekpunte te kan raaksien.

Die resultate van ' $n$ kritiese benadering kan dus van tweërlei aard wees. Aan die een kant 'n kritiese, maar verantwoorde verwerping van insigte wat nie met ' $n$ mens se eie basiese filosofiese sistematiek ooreenstem nie. Aan die ander kant egter óf ' $n$ versterking en verryking van jou eie voorlopige insigte, óf ' $n$ korreksie daarvan. ' $n$ Kritiese benadering is dus nie as sodanig iets negatiefs nie - selfs negatiewe resultate kan waardevol wees.

\section{Teties-krities}

Dit is baie belangrik dat Vollenhoven se tweesydige metode inhou dat die twee fasette daarvan wel onderskei, maar nie geskei mag word nie. Vir elke kritiese evaluering is 'n eie tetiese visie ' $n$ vereiste - anders verval ' $n$ mens in relativisme. Omgekeerd moet 'n Christelik-tetiese metode egter altyd die openheid toon om na ander menings te luister - anders ontaard dit in dogmatisme. Ywer ten opsigte van slegs een kant van die teties-kritiese metode voorspel dus probleme. Kok (1998) skryf:

When the relation between being thetical and being critical is forgotten, Christians lose a real sense of what ... being different means practically ... lack a sense of direction ... become mindless eclectics. (bl. 18)

Hy voeg by dat miljoene 'born again'-Christene se visie op sake van die dag op hierdie wyse dikwels geen verskil toon met dié van hulle sekulêre landgenote nie.

Dit bring 'n mens by die vraag wat Vollenhoven se eie tetiese visie dan presies inhou.

\section{Vollenhoven se eie ontologie in 'n neutedop}

Vollenhoven plaas sy eie werklikheidsvisie of ontologie openlik op die tafel, sodat 'n mens presies weet wat die vooronderstellings is waaruit hy die geskiedenis van die filosofie benader. (Hy het sy historiografiese metode nie op 'n goeie dag bedink nie, maar gevind ná 'n langdurige bestudering van die Westerse denke.) 


\section{'n Christelike filosofie}

Vollenhoven noem sy filosofie 'n Christelike filosofie, wat iets heeltemal anders beteken as Christene wat filosofie beoefen. Daarmee bedoel hy dat ' $n$ mens ook in jou filosofie Christus moet gehoorsaam en volg. Om 'n denker en 'n Christen te wees, is vir hom nie onversoenbaar nie (vgl. Tol 2010:386). Vandaar ook sy ander benaming, naamlik 'n skrifmatige wysbegeerte wat op 'n gehoorsame luister na God se drievoudige, skeppings-, Skrif- en vleesgeworde openbaring dui.

Terloops, op hierdie punt verskil hy radikaal van Allen, vir wie 'n Christelike filosofie 'n onmoontlikheid sou wees. Volgens haar natuur-genade dualisme sou slegs 'teologie' Christelik kon wees (vgl. Van der Walt 2014a).

\section{Die inhoudelike kern}

Wat maak Vollenhoven se filosofie dan skriftuurlik en wat behels dit inhoudelik? Hy vind die antwoord nie op 'n biblisistiese wyse nie, maar deur middel van 'n breër, rigtinggewende oriëntasie aan God se drievoudige openbaring. 'n Mens kan om twee redes nie 'n Christelike filosofie eenvoudig uit die Bybel aflees nie, want eerstens is die Woord van God nie 'n stuk filosofie nie, maar God se openbaring in voorwetenskaplike taal en tweedens neem die Skrif nie die moeilike taak uit die mens se hande om self filosofies (en op ander wyses) God se skepping te ondersoek nie (vgl. Tol 2010:257, 399).

Negatief maak dit van Vollenhoven 'n teenstander van 'n hiërargiese syn wat God, die kosmos en die mens omvat, sodat daar gevolglik tussen God, sy wet en die skepping slegs relatiewe verskille sou wees.

Positief kan sy eie ontologie egter soos volg saamgevat word: Vollenhoven's primary distinction was that of the triune God who is, the law for the cosmos that holds, and the created cosmos, which is entirely sustained by God. (Tol 2013 - vgl. ook Vollenhoven 2005a:14, 2005c:76; Tol 2010:489)

\section{Verder uitgespel}

Hierdie kerngedagte wat aan die Bybel ontleen is, het Vollenhoven (2005a) filosofies verder in sy Isagôgè philosophiae uitgewerk en hy verduidelik dit later weer kortliks (Vollenhoven 2011:29, 30). Volgens hom moet 'n volledige werklikheidsbeskouing rekening hou met drie radikaal verskillende en tog onskeibare werklikhede: God, sy wet, en die skepping.

Dat Vollenhoven ook met God in sy filosofie rekening hou - sonder om oor Hom te wil spekuleer soos die geval is in baie teo-ontologieë wat God as die objek van hulle studie beskou - was 'n byna revolusionêre stap. (In hierdie opsig verskil sy ontologie ook radikaal van dié van Allen.) Volgens Vollenhoven kan 'n mens nie die kosmos as skepping beskou sonder 'n Skepper nie. Sonder God as Wetgewer word wette ook bloot subjektiewe menslike bedenkings. Vollenhoven (2000:349) is egter baie duidelik daaroor dat sy onderskeid tussen God, die wet en die skepping nie beteken dat God ook 'n deel van sy ontologie is nie. Daarmee word bloot God se bestaan erken en nie veronderstel dat Vollenhoven oor God as 'n synde wou filosofeer nie.

'n Sekulêre een-faktorwerklikheidsvisie (wat net die kosmos erken), of 'n Christelike twee-faktorvisie ('n erkenning van slegs God en die skepping) is dus nie volledig of korrek nie. Drie werklikhede moet erken word, want tussen God en sy skepping staan God se wil soos in sy wette vir die skepping gestel.

Hierdie tussen-werklikheid dra nóg 'n goddelike, nóg 'n geskape karakter en dit is ook nie 'n kombinasie van albei nie. Nee, skryf Vollenhoven, teenoor God staan sy wette en die skepping. Hierdie teenoor is nie in 'n vyandige sin bedoel nie, maar dit dui op die wet en die skepping se afhanklikheid van Hom. Die wet is deur Hom gestel en die kosmos is deur Hom geskep. Die wet geld dus en die kosmos is wetsonderworpe. Dit het geen sin om van 'n wet te praat wat nie vir iets geld nie, of van 'n geskape iets wat nie onder God se verordening staan nie. (Vir meer besonderhede, vgl. Tol 2010:392-408.)

\section{Drieërlei wet}

Tot sover is die term wet breedweg gebruik. Vollenhoven (2005b) onderskei egter wet in drieërlei sin:

... the structural law is situated within creation [is related to creation]. The law of love stands between die Creator and humanity as the command of God's covenant. The positive law is neither situated within creation, nor can it be identified with the law of love. It is the bridge which comes into existence by being built in a given situation for the sake of a specific societal structure, in and through the office concerned with that social structure. It is built so as to connect the commandment of the law of love to human life in a structure battered by sin. (bl. 15, 16; vgl. ook Tol 2010:424)

In Vollenhoven (2011:30) volg 'n verdere verduideliking. Eerstens is God se struktuurwette daar as ontstaansbevel (vgl. Gen 1 \& Rom 4:17b). Hy bring die verskeidenheid kosmiese dinge voort bloot deur ' $n$ woord te spreek. Implisiet in God se ontstaansbevel is ook die 15 verskillende wetskringe en die ontwikkeling van die vier ryke van stof, plant, dier en mens ingesluit. Die ontstaansgebod is dus 'n struktuurgebod.

Tweedens is God se liefdesgebod nie 'n ontstaansbevel nie, maar ' $n$ gebod in die sin van 'n aanspraak op die mens wat reeds bestaan. Die liefdesgebod is nie 'n gebod wat die struktuur van dinge bepaal nie, maar 'n gebod wat tot die hart, die religieuse sentrum van die mens, gerig is om die rigting van sy en haar hele lewe ten goede te rig. Religie omvat vir Vollenhoven dus alles wat die mens dink en doen (vgl. Tol 2010:450, 482).

Ten derde is daar positiewe wette, positiverings van die liefdesgebod deur iemand in 'n gesagsposisie vir 'n bepaalde tyd en omstandighede op 'n spesifieke lewensterrein. In teenstelling tot die altyd-geldende liefdesgebod, geld menslike positiverings of norme dus slegs vir ' $n$ beperkte tyd, plek en terrein. 
Vollenhoven gebruik die voorbeeld van 'n parlementslid. As politikus sal die parlementslid nie oor God se liefdesgebod in die parlement preek nie - dit is die werk van 'n predikant. Die persoon sal egter wel as Christen optree deur liefde in die vorm van onpartydige geregtigheid (in bv. die landswette) te positiveer. Sulke wette is egter nie onfeilbaar en goddelik nie, maar wel normatief.

Hiermee is genoeg van Vollenhoven se eie filosofie verduidelik om sy benadering van die geskiedenis van die filosofie te kan verstaan.

\section{Die hoofonderskeidings van Vollenhoven se filosofiese historiografie}

Die trits, God-wet-kosmos, is die keurmerk van Vollenhoven se eie filosofie. Dit kom duidelik weer na vore in sy wysgerige historiografie. Hy onderskei drie hoofperiodes (as antwoorde op God se openbaring), verskillende tydstromings (as vergestaltings van verskillende wetsidees) en 'n verskeidenheid tipes filosofieë (wat verskillende visies op die skepping in die algemeen en die mens in die besonder voorstaan). Sáám bied hierdie drie elemente die konsepsie van 'n filosoof.

\section{Drie hoofperiodes}

Vollenhoven gaan in die eerste plek uit van die vraag na die verhouding van die Westerse denkers teenoor God se Woordopenbaring. Gedurende die tyd voor die koms van Christus het baie antieke Griekse, Hellenistiese en Romeinse denkers God se Woord nie geken nie. Hulle het as heidene geleef en gedink. Hierdie is die konstatering van ' $n$ feit en is nie bedoel om hierdie filosowe te brandmerk of te veroordeel nie. Hierdie periode van suiwer pagane denke duur tot ongeveer 50 n.C.

\section{Bevooroordeeld of nie?}

Beteken sodanige visie op die antieke filosofieë nie die toppunt van partydigheid of bevooroordeeldheid nie? Hierop is Vollenhoven (2005b) se antwoord ja en nee:

\begin{abstract}
Yes, in so far as one cannot risk advancing one step in this direction without having already chosen for or against Christ Who ever since the Fall into sin has been and ever remains the center of world history - in the great battle that encompasses all of history and therefore also philosophy. No, insofar as one transcends all partiality, exactly by making a choice here, even though not all Christians are aware of the partiality inherent in all conceptions of the current philosophy. (bl. 19)
\end{abstract}

\section{Sintesedenke}

Die tweede hoofperiode (ongeveer 50-1550 n.C.) word deur Vollenhoven (2011:25) as sintesefilosofie getipeer. (In die lig daarvan noem hy die eerste tydperk voorsintesedenke.) Hierdie era begin met die prediking van die evangelie dwarsoor Europa. Die resultaat was dat sommige heidene getrou gebly het aan hulle pagane gelowe, terwyl ander die verlossingsboodskap aangeneem het.
Die grootste deel van die jong Christene was natuurlik nie filosowe nie. Die enkele wysgere onder hulle was egter reeds goed geskoold in die heersende antieke denkgoedere. Omdat hulle ook die Skrif as gesagsvol aanvaar het en Christelik wou dink, lees hulle egter spontaan en onwillekeurig hulle reeds-aanvaarde, pagane filosofiese sisteme in die Skrif in (eisegese), omdat hulle van mening was dat die Skrif soortgelyke idees sou verkondig. Deur 'n daaropvolgende uitleg (eksegese) kry hierdie allermins Bybelse gedagtes egter goddelike sanksie.

Die gevolge hiervan was geweldig: ' $n$ bitter stryd is in die Vroeë Kerk reeds ten tye van die apostels gevoer - en ook nog vir baie eeue daarna. (Volgens 1 Joh 4:2-7 was sommige denkers byvoorbeeld van mening dat Christus nie werklik' $n$ mens was nie, terwyl ander volgens 1 Kor 15 die opstanding geloën het.)

\section{Antisintese-denke}

Gedurende die derde fase (vanaf ongeveer 1550 n.C.) word hierdiesintesementaliteit geleidelik verwerp. Diehooftendens word, hoewel om twee heeltemal verskillende redes, antisinteties. Sekulêre antisintetiese denkers het die Bybel as 'n mite, 'n outydse fabel beskou en dit uit hulle filosofiese denke verban. Daar was egter ook 'n Christelike rigting (bv. die sestiende-eeuse Reformasie) wat nie uit minagting met die Woord van God gebreek het nie, maar daaraan alleen die finale gesag toegeken het. Die akkommodasie wat die kerkvaders en die middeleeuers tussen die heidense filosofie en die goddelike openbaring wou bewerk, was volgens hulle 'n vergeefse poging wat vooraf tot mislukking gedoem was.

Vollenhoven self wil ook 'n Christelike antisintesedenker wees. Hierbo is reeds verduidelik dat dit nie dieselfde as (negatiewe) antitetiese denke behels nie.

\section{Verskil met Allen}

Ook in hierdie opsig is daar ' $n$ hemelsbreë verskil tussen Vollenhoven en Allen se historiografieë. As Roomse sintesedenker probeer Allen met 'n natuur-genademetode heidense en Christelike denkgoed versoen, al bestaan hulle vir haar op twee vlakke. Sy dink nie antisinteties Christelik soos Vollenhoven nie, want filosofie is vir haar 'n neutrale, redelike saak.

Die implikasie van Vollenhoven se standpunt is dat neutraliteit selfbedrog is. Meer nog: Wie en wat die mens ten diepste is (bv. 'n skepsel van God, 'n religieuse wese met 'n hart wat na God se liefdesgebod moet luister) kan die Woord van die Skepper alleen openbaar.

\section{Méér as net 'n Christelike gesindheid}

Vollenhoven lê klem daarop dat dit vir hom nie bloot om 'n Christelike gesindheid gaan nie, of om te bewys dat hyself ' $n$ Christen is deur byvoorbeeld net hier en daar ' $n$ kritiese opmerking te maak of ' $n$ Bybelteks aan te haal nie. Hy skryf:

... de kwestie 'Christen of niet-Christen' zit in het materiaal. Het schuilt ook by de onderzochten. Plato en Aristoteles 
waren heidenen. In de Middeleeuwen hebt ge te doen met christenmensen en tegenwoordig is het de vraag met wie ge hebt te doen. Met een Christen of met een niet-Christen? Daarmee hebt ge rekening te houden en dat heeft niets te maken met een gezindheid van het onderzoeker. Die moet er ook zijn ... maar dat is een kwestie van rigting bij het materiaal en dat moet worden onderkent, anders maakt men van Plato een Christen ... En dat komt zeker niet de bezinning op de geschiedenis van de wijsbegeerte ten goede. (Vollenhoven 2011:20-21)

Vollenhoven vervang dus die standaardhandboeke oor die geskiedenis van die filosofie se indeling van antieke, middeleeuse en moderne filosofie met 'n totaal nuwe periodisering. Hierdie drie hoofperiodes in die geskiedenis word deur Vollenhoven nog verder onderverdeel, aangesien binne elkeen van hulle talle verskillende filosofiese stromings in die loop van die geskiedenis na vore gekom het.

\section{Verskillende normatiewe stromings}

Van Vollenhoven se trits van God, die wet en die kosmos speel ook die wetsidee ' $n$ belangrike rol in sy analise van die filosofiegeskiedenis. Aan alle denkers moet nie net gevra word wat hulle verhouding tot die Woord van God en die God van die Woord was nie, maar ook wat hulle visie oor die plek en fundering van wette, kriteria of norme vir teorie en praktyk was (vgl. Vollenhoven 2005b:13, 2011:46). Behalwe die onties-strukturele vraag oor wat alles is of bestaan (en hulle onderlinge verhoudings), moet elke denker dus ook besin oor die normatief-direksionele vraag hoe gedink en gehandel behoort te word. Die antwoord op die eerste vraag lei tot ' $n$ bepaalde tipe ontologie terwyl 'n filosofiese stroming met die antwoord op die tweede vraag na vore kom (vgl. Vollenhoven 2000:404)

\section{Verskillende normatiewe visies}

Vollenhoven ontdek 'n groot verskeidenheid normatiewe stromings (vgl. Vollenhoven 2005b:153-155 vir'n geheeloorsig). Hier volg slegs drie voorbeelde aangesien dit onmoontlik is om op die detail in te gaan.

Plato (in sy finale fase) huldig die idee dat die wette as dinge (Latyn: res, vandaar die benaming van sy wetsidee as realisme) afsonderlik van die sigbare werklikheid bestaan. Hulle is egter blote voorbeelde vir dink en doen en dus nie werklike wette wat geld, gehoorsaamheid van iemand vereis en by oortreding straf kan verdien nie.

Plato se realistiese verdubbeling van die werklikheid het ná hom egter nie bevredig nie en 'n nuwe stroming het die Griekse denkers geboei, naamlik subjektivisme. Dit beteken dat die wette en die dinge waarvoor hulle moet geld nie meer duidelik onderskei is nie - die wette word in die dinge self gesoek, naamlik dit wat is, word dit wat behoort. (Genot of mag word byvoorbeeld ' $n$ norm in plaas daarvan dat dit normatief beoordeel word.)

'n Latere ontwikkeling tydens die Hellenistiese denke verplaas die normatiewe riglyne, wat tot dusver steeds buite die mens gesoek is, nou a priories na binne die mens se intellek. Dit berei op hierdie wyse die weg voor vir die latere rasionalistiese wetsidees (1600-1900), wat die menslike verstand verabsoluteer tot 'n outonome rede, 'n eie wetgewer, 'n afgod.

Die hele Westerse filosofie tot by die huidige postmodernisme huldig nog steeds een of ander subjektivistiese wetsidee. Omdat dit egter nie werklik normatiewe vastigheid kan bied nie, volg die een na die ander stroming mekaar op. (Vgl. bv. Venter 2011:108-143 wat verskeie moderne filosofiese stromings beskrywe.)

\section{Verskille met Allen}

Uit die vorige artikel het duidelik geblyk dat Allen subjektivisties ook die norm vir geslagtelike verhoudings in 'n spesifieke verhouding (dié van komplementariteit) vind. Die sentrale liefdesgebod kom nie by haar ter sprake nie, en ook nie die positivering daarvan vir 'n spesifieke terrein nie.

Verder hou Allen se weergawe van die geskiedenis ook nie rekening met die wyse waarop verskillende normatiewe stromings of kulturele tydperke denkers se visie aangaande die vrou beïnvloed het nie. Sy toon byvoorbeeld die ontiese ooreenkomste tussen Aristoteles en Thomas van Aquino aan, maar neem nie in berekening dat hulle in totaal verskillende periodes en denkstromings gelewe het wat hulle mensvisies medebepaal het nie.

Hoewel Vollenhoven ook nie eksplisiet op die invloed van denkstromings op denkers se visies ten opsigte van geslagtelikheid ingaan nie, is dit implisiet wel teenwoordig. Die rasionalisme was, as gevolg van hulle vergoddeliking van die menslike intellek, byvoorbeeld duidelik ten gunste van die meerderwaardigheid van die man (as die redelike wese), terwyl die eksistensialistiese irrasionaliste menslike, subjektiewe vryheid, ook dié van die vrou, as die norm beskou het.

Daar word nou oorgegaan tot die derde hoofelement van Vollenhoven se wysgerige historiografie.

\section{Verskillende visies op die kosmos}

Ook die laaste element van Vollenhoven se onderskeid, God-wet-kosmos, bepaal sy historiografie. Behalwe die normatiewe vraag, naamlik wat behoort gedink of gedoen te word (m.a.w. die rigting van die menslike lewe), moet die volgende vraag ook aandag ontvang, naamlik waaruit die kosmos en die mens as deel daaraan bestaan (hoe dit gestruktureer is) en hoe alles saamhang.

\section{Basiese kosmologiese probleme}

Reeds vroeg in die geskiedenis, by die bakermat van die Westerse denke in Griekeland, kom die volgende drie basiese vraagstukke na vore: Wat is die verhouding tussen stabiliteit en verandering, tussen eenheid en verskeidenheid, en tussen die individuele en die universele? (vgl. Vollenhoven 2011:45).

Soos uit die volgende duidelik sal word, lei al hierdie grondliggende ontiese probleme ook tot verskillende visies 
oor die mens en ook die dualiteit - nie te verwar met dualisme nie - van die menslike geslagtelikheid.

\section{'n Leemte by Allen}

Voordat verduidelik word wat die probleme behels, word 'n tersyde opmerking oor Allen se werk gegee. Sy fokus alleen op die hoër-laer onderskeid tussen die siel en die liggaam van die mens. Dit sou volgens haar óf tot die vrou (met die liggaamlike geassosieer) se geringskatting, óf tot haar oorskatting gelei het. Sy behandel egter nie die drie bogenoemde basiese ontologiese probleme wat vir die verskillende antropologieë bepalend is nie.

\section{Drie belangrike ontologiese vertrekpunte}

In hierdie afdeling word verduidelik wat hierdie drie probleme behels voordat op hulle antropologiese implikasies gelet word (vgl. ook Bril 1986, 2005).

\section{Konstantheid of verandering?}

Weens die beperkte ruimte word een standpunt hier buite die bespreking gelaat, naamlik die mitologiserende of teogonieskosmogoniese denke, wat filosofies gespekuleer het oor die wording van die gode en die kosmos. Vollenhoven (2005c:273) verwerp dit, omdat die Skrif 'n wordende veelgodendom verwerp en verder leer dat die kosmos deur één God geskep is - dit het nie vanself ontwikkel nie.

\section{Strukturalisme}

Op die vraag wat in die werklikheid vas is en wat verander, het ' $n$ eerste groep denkers die vastigheid daarvan benadruk. Omdat hulle strukture of die strukturele kant van die werklikheid oorbeklemtoon het, word hulle as strukturaliste aangedui. Vollenhoven (2005c:238) noem hulle ook suiwer strukturele of suiwer kosmologiese denkers. Hulle konsentreer dus net op die kosmos soos dit is en vermy enige verklaring oor die ontwikkeling of wording daarvan.

Vir die mensheid beteken so 'n visie dat hulle by die voorafbepaalde orde moet inskakel, die natuur waarvolgens elkeen moet lewe, is vooraf vasgestel. So 'n deterministiese visie neig dus ook na 'n vaste orde vir man- en vrouwees.

\section{Genetisisme}

Ander denkers het egter die klem op die genetiesveranderlike geplaas. Vollenhoven (2005c:216) noem hulle kosmogono-kosmologiese denkers - hulle wou ook logies oor die genese van die kosmos besin. Volgens hierdie denkers is die kosmiese strukture nie vas nie, maar wordend, vloeiend, bewegend, veranderend. Strukture word as 't ware opgelos in ' $n$ proses; die toekoms is nie gedetermineerd nie, maar oop.

Vir 'n mensbeskouing beteken hierdie standpunt dat die mens self vir sy en haar eie heil of onheil verantwoordelik is. (Dit is dus die omgekeerde van die strukturalisme wat passiwiteit en lydelikheid bevorder.) Daar bestaan ook nie 'n vaste orde nie, maar wel 'n neiging om normatiewe riglyne as heeltemal tydsgebonde en voorlopig te beskou. Genetisisme impliseer meestal ook dat geslagtelike verskille nie so belangrik is as wat dit by die strukturaliste is nie. Manlike en vroulike nature en hulle verhoudings is steeds in wording, onvoltooid.

'n Tweede basiese probleem deur die eeue was dié van eenheid of verskeidenheid.

\section{Eenheid of verskeidenheid?}

Enige opmerksame mens behoort getref te word deur die ryke verskeidenheid in die kosmos. Die vraag kan egter gevra word of alles ook op 'n manier saamhang. Is daar ook eenheid te midde van die geweldige groot verskeidenheid? Het die verskeidenheid ' $n$ oorsprong? Beteken eenheid dieselfde as enersheid en impliseer verskeidenheid dalk geskeidenheid?

Volgens Vollenhoven (2005c:117) leer die Bybel dat God die Oorsprong is wat alles geskep het. God se openbaring leer dus nóg 'n oorspronklike eenheid van alles (want volgens so 'n monisme word die verskil tussen God en sy skepping uitgewis), nóg 'n oorspronklike tweeheid (die dualistiese tweefaktorvisie is reeds hierbo bespreek).

Ook wat die skepping (kosmos) betref, is die korrekte standpunt nie eenheid en verskeidenheid nie, maar eenheid in verskeidenheid, anders word eenheid maklik enersheid en verskeidenheid word geskeidenheid.

In die geskiedenis van die Westerse denke is egter voortdurend stryd gevoer tussen eersgenoemde monistiese visie en laasgenoemde dualistiese standpunt. Omdat albei beskouings op 'n valse probleem (nl. die vraag of eenheid of verskeidenheid primêr is) 'n antwoord wou bied, kon hulle nooit tot ' $n$ finale oplossing kom of die een party die ander oortuig nie. (Vgl. Olthuis \& DeGraaff 1978:15-17 vir 'n duidelike weergawe.)

\section{Monisme en dualisme}

Die monistiese denkers was daarvan oortuig dat daar 'n fundamentele, oorspronklike maar ook finale eenheid in die werklikheid moes wees (vgl. Vollenhoven 2000:340). Die sin of betekenis van die menslike lewe soek hulle dus daarin om hierdie primordiale eenheid te midde van al die verskeidenheid te herwin en te realiseer.

Hierteenoor het dualistiese filosowe geglo dat daar 'n grondliggende, onherleibare gespletenheid, verdeeldheid of geskeidenheid bestaan wat altyd daar was en ook so sou bly. Volgens Vollenhoven (2000:294) is die hoëre gedeelte van hierdie twee-eenheid gewoonlik as die transendente gedeelte aangedui en die laere as die nie-transendente deel. Verskeidenheid is dus primêr en nie (soos by die monisme) van sekondêre aard nie. Dualistiese denkers se motivering is dus om 'n mate van samewerking of integrasie tussen die hoëre en laere elemente te bewerkstellig - 'n eenheid wat prinsipieel eintlik onmoontlik is. 


\section{Vervreemde tweelingbroers}

By die bestudering van ' $n$ denker moet ' $n$ mens dus versigtig wees om die eenheid waarvan daar sprake is, nie dadelik as monisme te beskou nie; of wanneer iemand baie oor verskeidenheid skryf, nie sommer dadelik die gevolgtrekking te maak dat sodanige denker ' $n$ dualis is nie. Die probleem van eenheid is 'n dualistiese probleem. Hoe kan 'n mens, uitgaande van 'n tweeheid, weer eenheid bereik? Omgekeerd is die monistiese vraagstuk ten diepste hoe om verskeidenheid te verklaar. Dualiste spandeer dus gewoonlik nie baie tyd om hulle uitgangspunt van ' $n$ tweeheid in die werklikheid te bespreek nie. Aangesien die eenheid vir moniste 'n gegewe is, funksioneer dit eweneens meestal net implisiet in hulle filosofie.

\section{Goed en kwaad}

Hoe verklaar die moniste dan die veelheid? Hulle beskou die verskeidenheid as hoëre en laere verdelings of afsplitsings uit die oorspronklike eenheid. Die dualiste moet op hulle beurt 'n verduideliking van die eenheid bied. Dit probeer hulle doen deur op die een of ander manier die afstand tussen die oorspronklike tweeheid van die transendente en die nie-transendente te oorbrug, sodat hulle in 'n verhouding tot mekaar kan staan.

Hieruit volg dat die twee standpunte mekaar sal bestry as gevolg van hulle verskillende visies op goed en kwaad. Vir die moniste is eenheid beter, volmaakter en goed, terwyl die verskeidenheid wat daaruit spruit minder goed of selfs sleg kan wees. Eenheid beteken verlossing van die kwaad. Omdat die hoëre, of transendente volmaakter of beter as die nie-transendente vir die dualiste is, beteken heil vir hulle dat die laere onderdruk of oorkom moet word, terwyl die hoëre as ideaal nagestreef word.

\section{Antropologiese implikasies}

'n Volgende skynprobleem was natuurlik hoe 'n monis se voorstelling van die verhouding tussen die hoëre en laere aftakkings (uit die oorspronklike eenheid ontstaan) sal wees. Verskillende antwoorde is bedink. Hulle kan byvoorbeeld mekaar weerspreek, die hoëre kan as belangriker as die laere beskou word, daar kan 'n wisselwerking tussen albei wees, of hulle kan geen kontak met mekaar onderhou nie. Verdere spekulasie toon egter aan dat by elkeen van hierdie vier moontlikhede nog fynere onderskeidings ook moontlik is (vgl. hieronder).

Op 'n soortgelyke wyse moes die dualiste ook spekuleer oor hoe presies die verhouding tussen die hoëre en laere in die mens gestruktureerd is. Is die mens byvoorbeeld ' $n$ volledig nie-transendente, kosmiese wese of is slegs sy of haar siel of gees dalk van transendente oorsprong? (Allen huldig heel waarskynlik laasgenoemde visie.)

Nou duik 'n volgende valse probleem egter op, naamlik of slegs die man 'n redelike transendente siel besit en vroue nie. Sommige digotomistiese denkers het net die rede tot die hoëre (transendente) deel van die mens gereken. Slegs mans het dus iets transendents besit. Ander digotomiste het ook die gevoel (tipies van die vroulike aard) as iets transendents beskou. In die eerste geval praat Vollenhoven dus van andrologiese dualisme (afgelei van die Grieks vir man) en in laasgenoemde geval van antropologiese dualisme (afgelei van die Grieks vir mens). (Vgl. Vollenhoven 2000:268, 418; 2005c:117.)

Die derde vraagstuk waaroor die Westerse denkers deur die eeue besin en verskil het, was die voorrang wat die individuele of die universele geniet het.

\section{Is die individuele of die universele die belangrikste?}

Die probleem in hierdie geval was om te bepaal wat die verhouding tussen die individuele (hierdie mens, man of vrou) en die universele (menswees, man- of vrouwees) sou wees en watter een van die twee die belangrikste was.

\section{'n Verkeerde vraagstelling}

Vollenhoven beskou hierdie vraag ook as 'n valse probleemstelling, omdat hy nie van die individuele en die universele wil praat nie, aangesien hulle slegs fasette van dieselfde geskape dinge is. Verder is dit ook nie so dat die universele faset belangriker as die individuele sou wees of omgekeerd nie. Die man en die vrou toon individuele verskille, maar ook universele ooreenkomste (albei is mense). Selfs by elkeen van die twee geslagte is daar individuele verskille tot op geneties-biologiese vlak. Individuele verskille impliseer ook nie minder- of meerderwaardigheid nie. (Die universeel-individuele onderskeid is ook nie op God van toepassing nie.)

Die universele kante van dinge is egter in die geskiedenis as dinge of gedeeltes van dinge beskou (vgl. Vollenhoven 2000:354-355, 2005c:313). Omdat wette universeel of algemeen geld, is die universele ook dikwels met die wet vereenselwig - nog 'n verwarring.

\section{Verskillende teorieë}

Die stryd tussen die universaliste en die individualiste loop dwarsdeur die geskiedenis (vgl. Vollenhoven 2000:354). Eersgenoemde het geleer dat die universele die primêre was, terwyl die individuele slegs uitlopers daarvan sou wees. Daarteenoor was die individualiste oortuig dat die universele (as die sekondêre) slegs by die grasie van die denke of die praktiese handelinge van individue sou bestaan.

Die gedeeltelike universaliste bedink 'n soort tussenstandpunt, omdat hulle ingesien het dat die universele en die individuele nie as dinge van mekaar geskei kan word nie - dit moes dele van dieselfde ding wees. Onderling kon hulle egter nie eenstemmigheid bereik oor hoe presies dit die geval was nie.

Sommige van hierdie denkers het ' $\mathrm{n}$ horisontale verhouding tussen die universele en individuele gesien. As die grotere en die kleinere, wat na mekaar lyk, sou die universele en die individuele langs mekaar voorkom. Alles in die een (groot) wêreld of hemel is ook in die (kleine) verskeidenheid van 
die mens en ander dinge teenwoordig, asook omgekeerd. Dit is die bekende makro- en mikrokosmosleer. As gedeeltelike universalisme bly die universele egter belangriker as die individuele.

Ander gedeeltelike universaliste was egter van mening dat die universele en die individuele nie langs mekaar nie, maar onder mekaar in dieselfde ding sou bestaan - dus 'n vertikale teorie. Dit is die bekende vorm- en materieleer. Ook hier kom egter onderlinge verdeeldheid, omdat die hoëre vir sommige denkers die universele was, terwyl die universele vir ander in die laere (materie) te vinde was.

\section{Antropologiese implikasies}

Ook hierdie derde ontologiese probleem het gevolge vir die wyse waarop die mens as man en vrou gesien word. Allen behandel egter glad nie hierdie saak nie. Sy behandel wel Aristoteles en Thomas, al twee voorstanders van die vormen materieleer, maar sien nie die diepere probleem (waarvoor dit 'n oplossing bied) raak nie.

Hoewel Vollenhoven ook nie aandui wat alles in sy grondiger ondersoek opgesluit lê nie, kan maklik afgelei word wat dit vir die kwessie van geslagtelikheid inhou. Volgens die vertikale gedeeltelike universalisme is die vorm byvoorbeeld die hoogste, universele en aktuele, die naaste aan die goddelike, wat suiwer vorm sou wees. Dit staan bokant die laere, individuele, blote potensiële materie, wat die verste van goddelikheid verwyder is. Bowendien word vorm met manlikheid, redelikheid en normatiwiteit verbind en vroulikheid met die passiewe, blote potensiële materie. Hierin - en nie in blote misogenie nie - lê die diepere ontiesantropologiese oorsake vir Aristoteles en Thomas (en baie ander denkers) se minagting van die vroulike geslag.

Baie Middeleeuse vrouedenkers het hulle (om verstaanbare redes soos die ideaal van maagdelikheid) tot die (semi-) mistiek aangetrokke gevoel. Heel waarskynlik was ook Allen se uitverkore vroulike denker, Hildegard van Bingen (1098-1179) 'n semi-mistieke filosoof. Volgens Vollenhoven (2005c:377, 418) veronderstel so 'n visie 'n dualistiese ontologie en 'n trigotomistiese antropologie, naamlik dat die hoogste deel van die mens se siel van goddelike afkoms sou wees en weer na' $n$ mistieke, ontiese eenheid met God behoort terug te streef. In so 'n visie kan goed en kwaad ook nie gesien word as ' $n$ religieuse konflik tussen gehoorsaamheid en ongehoorsaamheid aan God nie, maar as 'n konflik tussen 'n hoëre siel of gees en die laer, liggaamlike behoeftes.

Tot sover is slegs hier en daar by wyse van voorbeelde aangetoon wat hierdie drie ontologiese visies se antropologiese implikasies kan wees. Vervolgens word die aandag meer eksplisiet op die verskillende antropologieë toegespits.

\section{'n Groot verskeidenheid mensvisies}

Tot sover het dit ook duidelik geword dat 'n denker se werklikheidsvisie of ontologie op ' $n$ beslissende wyse bepaal hoe sodanige denker se mensvisie of antropologie sal lyk.
(Baie denkers verklap natuurlik nie hulle ontologie vooraf nie, sodat ' $n$ mens dit terugwerkend uit hulle mensvisies moet aflei, of selfs uit hulle kenteorieë moet probeer rekonstrueer.) Die debatte tussen strukturalisme en genetisisme, monisme en dualisme, tussen individualisme, universalisme en die verskillende vorms van gedeeltelike universalisme toon ook die neiging om 'n ontologiese grondstruktuur te vorm met ' $n$ daarmee samehangende patroon of konstellasie van temas. So 'n denktradisie lei tot spesifieke mensvisies (vgl. Vollenhoven 2000:367). Moniste is byvoorbeeld tot genetiese denke geneig, terwyl dualisme gewoonlik met strukturalisme gepaard gaan (vgl. Olthuis \& DeGraaff 1978:21).

\section{Medebepaal deur verskillende stromings}

Soos reeds vroeër vermeld (vgl. 'Verskillende normatiewe stromings') word mensvisies egter nie net deur ontologiese probleme nie, maar ook deur die betrokke normatiewe stromings waarbinne 'n denker staan, medebepaal. (Vir 'n oorsig oor die talle stromings en verteenwoordigers daarvan, vgl. Vollenhoven 2005b:153-156.) Terwyl die ontiese tipes die struktuur van die kosmos en die mens beskryf, gaan dit in die stromings oor hoe die mens volgens sekere kriteria in die wetenskap behoort te dink en in die praktyk behoort op te tree, met ander woorde oor die koers of rigting van die lewe tydens ' $n$ bepaalde kulturele epog.

'n Bepaalde tipe filosofie (bv. monisme of dualisme) kan dwarsdeur die geskiedenis en dus by verskillende opeenvolgende stromings voorkom. Dit gee dus 'n mate van konstantheid en kontinuïteit aan die Westerse filosofie. 'n Tydstroming is egter eenmalig, van verbygaande aard en verantwoordelik vir die dinamiek van die geskiedenis. Omdat norme meestal subjektivisties in die dinge self gesoek word, is ' $n$ byna onbeperkte aantal stromings moontlik. (Vgl. bv. hoe alles in ons eie tyd verkommersialiseer word.) 'n Nuwe tydstroming transformeer gewoonlik ook 'n ouere/ vroeëre tipe filosofie.

Struktuur en rigting kan dus wel onderskei maar ook in die mensvisies nie geskei word nie. Weens ruimtegebrek moet die mensvisies wat vervolgens as voorbeelde bespreek word, tot hulle strukturele kante beperk word.

'n Voorbeeld hiervan is reeds genoem toe aangetoon is dat sowel by die mitologiserende dualistiese as die kosmogonokosmologiese denkers digotomistiese mensvisies voorkom. Dit is die geval omdat óf geglo word dat alle mense oor iets transendents (bv. 'n siel) beskik soos die antropologiese tipe, óf gemeen word dat dit slegs die geval by mans is, naamlik 'n andrologiese digotomie.

As gevolg van die groot verskeidenheid mensvisies beperk die outeur hom tot voorbeelde van monistiese kosmogono-kosmologiese antropologieë om ten slotte slegs enkele opmerkings oor dualistiese, suiwer kosmologiese mensbeskouings te maak. 


\section{Voorbeelde van monistiese kosmogono- kosmologiese antropologieë}

Die leser word daaraan herinner dat kosmogonokosmologiese denke genetiese en nie statiese strukturele denke is nie. Monisme gaan ook van 'n veronderstelde primêre oorspronklike eenheid van die werklikheid uit, wat in 'n sekondêre veelheid verdeel kan word.

Vollenhoven (2000:418-419) onderskei vier hoofgroepe (met verdere subvariasies) na aanleiding van hoe denkers hulle die verhouding tussen die hoër en laere divergensie uit die eenheid voorgestel het. Die hoofgroepe is naamlik die saamval van teenstrydige divergensies ('contradictory anthropologies'), die prioriteitsleer, verskillende wisselwerkingsteorieë en parallellisme. (Vgl. ook Olthuis \& DeGraaff 1978:23-30; Bril, 1986:127-134 vir waardevolle diagramme om die verskille te visualiseer. ' $n$ Konkrete voorbeeld is Van Belle 1980:94 se tipering van die psigoterapeut Carl Rogers as 'n genetiese monis.)

\section{Die teorie van 'coincidentia oppositorum'}

Hierdie teorie oor die mens is seker die ingewikkeldste van al die monistiese mensvisies. Dit leer dat, gelyktydig met die proses van verdeling uit die eenheid tot 'n hoër en laer dimensie, die teenoorgestelde proses ook terug na die eenheid plaasvind. Die verhouding is dus ' $n$ eenheid van teenoorgesteldes (Latyn: coincidentia oppositorum). Hierdie tweerigtingproses is inherent teenstrydig en ewigdurend.

Hierby kan gevoeg word dat die rigting vanuit die eenheid (dié van verdeling) 'n tydsrigting is, terwyl die rigting terug na die eenheid of die oorsprong as ewig, universeel en heilig beskou word. Die mens moet by hierdie universele, deterministiese proses inskakel. Volgens Olthuis en DeGraaff (1978:29) word goed en kwaad, manlik en vroulik en alle ander teenstellings slegs as opeenvolgende momente in die ontplooiing van die universeel-goddelike proses beskou.

\section{Variasies binne die prioriteitsleer}

'n Volgende vorm van genetiese monisme is die gedagte dat die hoëre bifurkasie of afsplitsing vanuit die primêre eenheid voorkeur geniet bo die laere. Daar bestaan slegs 'n eenrigtingverkeer. Die hoëre het die laere wel nodig, maar slegs in dié sin dat dit die laere regeer en as werktuig gebruik en beïnvloed - omgekeerd het die laere geen invloed op die hoëre nie. Hierdie antropologiese visie word daarom as 'n prioriteitsleer aangedui.

\section{Vier verskillende tipes}

Gewoonlik word 'n basiese antropologiese standpunt mettertyd in verskillende variasies uitgewerk. Hierdie subteorieë hang af van waar die grens tussen die hoëre en laere afsplitsing van die oorspronklike eenheid geplaas word (vgl. Vollenhoven 2000:371-373, asook Bril 1986:128-129 vir verhelderende sketse).

Indien die fisies-organiese (die ryk van stof en plant) as die laere divergensie beskou word, is die neiging om die laere met min respek, slegs as 'n instrument van die hoëre te beskou. So 'n antropologie word 'n instrumentistiese prioriteitsleer genoem.

By 'n volgende tipe, die vitalistiese prioriteitsleer, sluit die laere divergensie, behalwe die fisies-organiese, ook die vitale in en die hoëre bevat die siel (psigiese) en die gees. In hierdie geval is daar ' $n$ groter waardering vir die laere afsplitsings as by die instrumentisme.

Ander filosowe het egter nog 'n derde antropologiese teorie bedink, naamlik die okkasionalistiese prioriteitsleer. Hiervolgens bestaan daar nie net 'n hoëre siel nie, maar ook 'n laere (dierlike) siel naas die liggaam. Die laere bied dus die geleentheid (Latyn: occasio) vir die hoëre om - soos 'n ruiter sy perd stuur - op die laere in te gryp en dit te beheer.

'n Vierde tipe prioriteitsleer is die ennoëtisme (afgelei van en $=$ in + nous $=$ denkgees). Hiervolgens is daar 'n denkgees in die hoëre, terwyl die laere uit die siel en die liggaam bestaan. Hoewel die siel die liggaam beïnvloed, is die hoëre denkgees - in teenstelling tot die okkasionalisme - nie sturend nie, maar slegs beskouend en beoordelend by die laere betrokke. Dit lei tot 'n groot mate van passiwiteit by die mens.

\section{Implikasies}

Olthuis en DeGraaff (1978:25) sê dat alle vorms van die prioriteitsleer daartoe neig om die kwaad in die laere afsplitsing te lokaliseer. Indien daar byvoorbeeld tussen intellek, wil en gevoel by die mens onderskei word, word die (laere) gevoelslewe van die mens as verdag beskou en moet die intellek en die wil dit onder beheer hou. In plaas daarvan dat die onderskeid tussen goed en kwaad as die regte of die verkeerde normatiewe rigting gesien word, word dit dus in die strukturele samestelling van die mens gesoek. Indien vroulikheid dus met die emosionele vereenselwig word, is die implikasies duidelik - die manlike geslag (met rede en wil geassosieer) moet dan oor die minderwaardige vroulike heers.

\section{Wisselwerkingsteorieë}

'n Ander groep denkers verwerp die verskillende prioriteitslere, omdat hulle van mening was dat die laere nie aan die hoëre onderworpe is nie, maar dat daar moontlik wedersydse wisselwerking tussen hulle bestaan. Uit die interaksie tussen die twee ontplooi die lewe. Die laere (bv. die biologiese en die psigiese) kan gevolglik ook 'n positiewer rol speel, sodat menslike passiwiteit nie langer (soos by die prioriteitsleer) ' $n$ kenmerk is nie.

\section{Variasies}

Soos by die vorige tipes antropologieë lewer hierdie hooftipe ook verskillende subtipes op. Vollenhoven (2000:414) het aanvanklik net drie sodanige variasies onderskei, maar later nog meer. Die onderlinge verskille hang af van waar die skakel of punt van afsplitsing tussen die hoëre en die laere vanuit die oorspronklike eenheid geplaas word en wat 
gevolglik die inhoud van albei sou wees. Die artikel word beperk tot Vollenhoven se vroeëre onderskeiding tussen slegs drie hooftipes.

Die fitologiese wisselwerkingsteorie (afgelei van die Grieks phuton $=$ plant) het geleer dat daar geen wesenlike verskil tussen plant, dier en mens bestaan nie. ('n Mens sou dit biologisme kon noem.) Volgens die soölogiese tipe word egter geleer dat die mens en die dier (in teenstelling tot die plante) albei 'n gevoelslewe het. ('n Mens sou dit animalisme kon noem.) Hierteenoor was die voorstanders van'n antropologiese wisselwerkingsteorie oortuig dat daar 'n fundamentele verskil tussen die mens en die dier bestaan.

\section{'n Besondere tipe}

Onder die nuwe tipes wisselwerkingsteorieë wat Vollenhoven (2000:9) later ontdek het, word met die oog op die slot van hierdie artikel (vgl. "n Mate van verwantskap'), ook nog die pneumatistiese genoem (afgelei van die Grieks pneuma = gees). Volgens hierdie mensbeskouing is daar ' $n$ vertikale divergensie uit die oorsprong of sentrum na 'n hoëre en laere ontiese niveau. Maar daarnaas is daar vanuit die sentrum ook ' $n$ horisontale differensiasie en integrasie. Hierdie sentrum is die pneuma wat menswees van binne en van buite rig of lei.

\section{Parallellisme}

Soos die naam aandui, bestaan daar in hierdie antropologie geen interaksie tussen die hoëre en die laere afsplitsings uit die primêre oorsprong nie. 'n Gebeure in die hoëre gaan gepaard met of is gesinkroniseerd met dieselfde gebeure in die laere. Vir parallelliste is dit dus belangriker as vir ander monistiese teorieë wat sover bespreek is om weer die oorspronklike eenheid terug te wen - daarsonder sou hulle teorie in dualisme eindig (vgl. Olthuis \& DeGraaff 1978:27). Die strewe is dus na koördinering, harmonie en balans.

Wat sou die implikasies van so 'n teorie vir die kwessie van menslike geslagtelikheid wees? Volgens Allen se terminologie sou dit heel moontlik 'n komplementariteitsmodel impliseer. Wanneer 'n mens egter in ag neem dat by die parallelliste ook twee subtipes voorkom (beperkte en onbeperkte parallelliste), is die implikasies nie meer so eenvoudig nie.

\section{Terug na Allen}

Indien bogenoemde vier hooftipes monistiese ontiesantropologiese teorieë as voorbeelde geneem word, word dit baie duideliker waarom Allen die verskillende verhoudings tussen die twee geslagte in die geskiedenis kon onderskei. Die eerste (waarin die hoëre en die laere mekaar sou weerspreek en tog saamval) kon sy óf as polariteit, óf as eenheid beskou. Die tweede (die prioriteitsleer) sou duidelik tot die meerderwaardigheid van die manlike lei (haar polariteitsteorie). In die geval van die wisselwerkingsteorie sou Allen se komplementariteitsmodel die verhouding tipeer. Uit die vierde (parallellistiese antropologie) sou Allen meer as een soort verhouding kon aflei.

\section{Dualistiese suiwer kosmologiese antropologieë}

Hierdie artikel is nie bedoel om ' $n$ volledige uiteensetting te bied van al die verskillende antropologieë wat Vollenhoven in die geskiedenis ontdek het nie. Die artikel wou slegs aantoon hoe antropologiese uitgangspunte ook 'n mens se visie op geslagtelikheid beïnvloed. Hierdie groep word slegs kortliks behandel.

Soos reeds genoem, dink hierdie denkers strukturalisties, in terme van statiese vaste strukture, terwyl verandering en ontwikkeling as minder belangrik beskou word. Hulle gaan as dualiste ook uit van twee oorspronklike entiteite, naamlik 'n hoëre of transendente en 'n laere, nie-transendente werklikheid. Die transendente word met eenheid en ewigheid en die nie-transendente met verskeidenheid en tydelikheid vereenselwig.

Ook hieruit spruit ' $\mathrm{n}$ hele aantal mensvisies. Vollenhoven (2005b:158-159) onderskei die volgende sewe hooftipes (met verdere variasies by elkeen van hulle): empirisme (konsekwente en nie-konsekwente), semi-mistiek (met drie subtipes), monargianisme ('n Platoniserende en 'n niePlatoniserende, met verdere subtipes), subsistensieteorie ('n Platoniserende en 'n nie-Platoniserende), die vinculumteorie ('n intellektualistiese en voluntaristiese tipe) en semi-materialisme (sonder en met digotomie). Vir ' $n$ verduideliking van wat elkeen van hierdie mensvisies inhou, kom Vollenhoven (2000:260 e.v.) handig te pas.

\section{Terugskouende samevatting}

Uit die voorafgaande uiteensetting is dit duidelik dat verskillende denktradisies (of tipes) telkens weer in opeenvolgende periodes (tydstromings) aangepas word. Vollenhoven (2000:184-259) is met sy metode in staat gestel om die hele ingewikkelde legkaart van die Westerse intellektuele geskiedenis skematies en oorsigtelik saam te vat. Diagrammaties bestaan dit uit vertikale en horisontale lyne wat mekaar kruis en só blokkies vorm waarin die konsepsie van ' $n$ bepaalde filosoof verskyn. Aan die regterkant van die horisontale lyne word verskillende lyne saamgevoeg om die geheel in drie hoofperiodes in te deel (voorsintese-, sinteseen antisintesedenke). Aan die linkerkant van die horisontale lyne verteenwoordig elke spasie tussen twee lyne 'n nuwe tydstroming. Die vertikale lyne (en die blokkies wat hulle vorm) dui van bo na onder eers die breë ontologiese visies aan (strukturalise of genetisisme, monisme of dualisme, universalisme, gedeeltelike universalisme of individualisme) en daarna die verskillende antropologiese standpunte (vgl. Van der Walt 2010c:174 vir 'n diagram hiervan). Let egter daarop dat hierdie Schematische Kaarten niks meer wil wees as wat die naam self sê nie. Dit is slegs bedoel indien 'n mens vinnig 'n filosoof se konsepsie(s) of die invloed van een denker op 'n ander wil nagaan.

$\mathrm{Na}$ 'n oorsig oor hierdie legio mensbeskouings wat die geskiedenis opgelewer het, sou 'n mens egter graag wou weet hoe Vollenhoven se eie antropologie daar uitgesien het. Dit is immers duidelik dat sy metode krities teenoor hulle almal is. Ten slotte dus iets daaroor. 


\section{Vollenhoven se eie mensvisie}

Vollenhoven het telkens sy metode verander om op ' $n$ beter wyse reg te kan laat geskied aan die groot verskeidenheid filosofiese ontologieë en antropologieë van die 2750-jarige Westerse denke. Teen die einde van sy lewe was hy nog steeds met belangrike hersienings besig wat hy egter, helaas, nie kon afhandel nie. Die geskiedenis van die filosofie het hom so in beslag geneem dat hy ook na 1945 nie meer sy eie visie verder kon uitwerk nie. 'n Manier om tog meer daaroor uit te vind, sou wees om te vra of daar nie darem een of meer historiese mensvisies was waarmee hy ten minste naastenby kon saamstem nie.

\section{'n Mate van verwantskap}

Vollenhoven het 'n relatiewe voorkeur gehad vir die reeds genoemde (sien 'W isselwerkingsteorieë', 'n besondere tipe) monisties-pneumatistiese wisselwerkingsteorie. Sonder om daarvan 'n aanhanger te wees, was Vollenhoven (2005c:440) van mening dat so 'n antropologie die meeste reg laat geskied het aan die geskape werklikheid of stand van sake. Hierdie antropologie vind hy onder andere by Gregorius van Nazianze (329-390 n.C).

Uit wat Van der Walt (2010a:302-304) hieroor skryf, blyk ook waarom Vollenhoven simpatie vir Gregorius se visie gehad het. Heel waarskynlik omdat die menslike, innerlike gees (Grieks: pneuma) volgens die pneumatistiese wisselwerkingsteorie ' $n$ rigtinggewende invloed op die uiterlike, liggaamlike sou hê - sonder dat die omgekeerde invloed van die uiterlike, fisies-biologiese op die innerlike mens ontken word. Dit toon verwantskap met die sentrale, religieuse rol wat Vollenhoven aan die menslike hart toeken.

Vollenhoven kon egter nie volledig met Gregorius instem nie, om die volgende redes: Gregorius was nog 'n sintesedenker; hy het Gregorius se monisme verwerp; Gregorius skryf nog steeds in digotomistiese terme oor die innerlik-uiterlike van die mens; hierdie ou kerkvader het nog nie werklik die hart as die religieuse sentrum van die mens raakgesien nie.

\section{Nie heeltemal onduidelik nie}

Van der Walt (2010a:305 e.v.) bespreek verder die volgende trekke van Vollenhoven se eie mensbeeld.

\section{Die hoër-laer word met innerlik-uiterlik vervang}

Dit is duidelik dat Vollenhoven die hoër-laer skemas van sowel die monistiese as die dualistiese antropologieë verwerp, aangesien dit onherroeplik daartoe lei dat iets van die mens oorskat word, terwyl ander fasette gedepresieer word. Hy vervang dit met 'n 'binne-buite' model.

Hy verwerp ook visies wat 'n aantal funksies van die mens (die psigiese tot die geloofsaspek) as 'n afsonderlike deel van menswees saamgroepeer teenoor 'n sogenaamde laere komponent (die aritmetiese tot die organiese).

\section{Die menslike hart en die alomvattende religie word herontdek}

Hoewel die mens volgens hierdie visie veel meer fasette het as byvoorbeeld net verstand, wil en gevoel en ook 'n veel ryker en komplekser wese as die dier is, is die mens nie 'n blote funksionele wese nie. Die innerlike hart is vir Vollenhoven iets prefunksioneels. Dit is die religieuse kern van die mens van waaruit sy en haar hele lewe gerig word (vgl. weereens Van der Walt 2010a).

Vollenhoven (2005a:78) omskryf religie as 'the relationship of humankind to the God of the covenant in obedience or disobedience to his fundamental law of love'. Hieruit blyk onder andere weer die sentrale plek van die liefdesgebod in Vollenhoven se denke. Al gehoorsaam iemand nie God of sy wet nie, is en bly die persoon nogtans 'n religieuse wese.

\section{'n Nuwe visie op die beeld van God}

Vollenhoven het ook 'n unieke visie op die Bybelse openbaring gehad, naamlik dat die mens na die beeld van God geskep is en na die sondeval weer uit genade daarna vernuwe kan word (vgl. Van der Walt 2010b). In die Christelike tradisie word die beeld van God nog steeds deur baie denkers as iets onties en semi-goddeliks in die hoëre deel van die mens geplaas. Volgens Vollenhoven was dit nog 'n mistasting wat die radikale onderskeid tussen God en die mens afwater. Die beeld van God is nie êrens in die mens nie. Die hele mens vertoon die beeld van God in die mate wat God se liefdesgebod (teenoor Hom en die naaste) gehoorsaam word.

\section{'n Nuwe samelewingsfilosofie}

Soos reeds genoem (vgl. 'Drieërlei wet'), het die mens die roeping om die goddelike liefdeswet, in ooreenstemming met die struktuurwette vir bepaalde lewensterreine, te konkretiseer of te positiveer.

Dit geld ook die verskillende moontlike verhoudings tussen die twee geslagte, asook verskillende relasies van amp, mag, gesag en verantwoordelikheid waarin vroue en mans kan staan. Alle menslike verhoudings, ook dié tussen die geslagte, is gekwalifiseerd. Dit is byvoorbeeld godsdienstig, eties, juridies, ekonomies, sosiaal of emosioneel van aard. Om soos Allen net drie algemene, ongekwalifiseerde soorte verhoudings tussen die man en die vrou te onderskei, beteken ' $n$ onaanvaarbare beperking en veralgemening.

Saamgevat, bied Vollenhoven 'n veel breër en dieper kyk op menswees en geslagtelikheid. Tol (2013) tipeer hierdie Christelike denker raak in die volgende woorde: 'Vollenhoven was a person who combined direct clarity with deep insight. He had an analytical mind ...'

\section{'n Laaste vraag}

'Goed', sou iemand aan die einde van hierdie verkenning kon sê, 'dit is waar dat Vollenhoven 'n magistrale bydrae gelewer het om die ontiese en antropologiese grondslae van menswees bloot te lê. Maar die vraag bly nog hinder waarom 
Vollenhoven hom nie eksplisiet oor die kwessie van menslike geslagtelikheid uitgespreek het nie.'

Hieroor kan alleen gegis word. Sommige (feministiese) denkers sal dit waarskynlik daaraan toeskryf dat Vollenhoven - soos 'n tipiese manlike filosoof - nog steeds seksisties gedink het. Ander denkers sou kon argumenteer dat juis omdat hy nie paternalisties gedink het nie, dit nie vir hom 'n belangrike vraagstuk was nie. 'n Derde opsie is dat geslagtelike dualiteit dalk vir hom eenvoudig 'n feit, miskien net nog een van die baie raaisels van menswees was, waaroor hy nie wou spekuleer nie. 'n Mens sal nooit weet nie.

Wat wel vasstaan, is dat Vollenhoven nêrens (soos Calvyn of Kuyper; vgl. Van der Walt 2014a) op vernederende en minagtende wyse oor vroue geskryf het nie. Hy maak tewens geen onderskeiding in hulle menswees nie. Albei geslagte is deur God na sy beeld geskep; het dieselfde kultuuropdrag van Hom ontvang; het al twee in sonde geval - wat ook hulle verhouding aangetas het; die verskillende strawwe aan hulle opgelê (Gen 3:16-19) mag ook nie verkeerdelik as ewigdurende norme beskou word nie, omdat al twee kan deel in die verlossing deur Christus. Daarom 'maak dit nie meer saak of iemand Jood of Griek, slaaf of vry, man of vrou is nie: in Christus is almal één' (Gal 3:28).

\section{Erkenning \\ Mededingende belange}

Die outeur verklaar dat hy geen finansiële of persoonlike verbintenis het met enige party wat hom nadelig of voordelig kon beïnvloed in die skryf van hierdie artikel nie.

\section{Literatuurverwysings}

Allen, P., 1985, The concept of woman, William. B. Eerdmans Publishing Company, Grand Rapids.

Bril, K.A., 1986, Westerse denkstructuren: Een probleem-historische onderzoek, Vrije Universiteit Uitgeverij, Amsterdam.

Bril, K.A., 2005, Vollenhoven's problem-historical method: Introduction and explorations, Dordt College Press, Sioux Center.

Kok, J.H., 1998, Patterns of the western mind: A reformed Christian perspective, Dordt College Press, Sioux Center.
Olthuis, J.H. \& DeGraaff, A.H., 1978, Criteria for comparing and evaluating models of man, Institute for Christian Studies (Mimeograph), Toronto.

Seerveld, C.G., 2014, 'From systematic suppression of woman to an asymmetrical gender mutuality', in C.G. Seerveld \& J.H. Kok (ed.), Collected works, vol. 3, ch. 6 . (To be published by Dordt College Press, Sioux Center)

Storkey, E., 1995, 'Dooyeweerd's anthropology - The male-female dimension', in S. Griffioen \& B.M. Balk (eds.), Christian philosophy at the end of the twentieth century, pp. 85-92, Kok, Kampen.

Tol, A., 2010, Philosophy in the making: D.H.Th.Vollenhoven and the emergence of reformed philosophy, Dordt College Press, Sioux Center.

Tol, A., 2011, 'Reformational philosophy in the making', Philosophia Reformato 76(Dec.), 187-215.

Tol, A. 2013, 'Vollenhoven, Dirk Hendrik Theodoor', in Wikipedia, viewed 31 October 2013, from http://en/wikipedia.org/wike/D.H.Th. Vollenhoven

Tol, A. \& Bril, K.A. (reds.), 1992, Vollenhoven als wijsgeer: Inleidingen en teksten, Buijten \& Schipperheijn, Amsterdam.

Van Belle, H.A., 1980, Basic intent and therapeutic approach of Carl R. Rogers, Wedge Pub. Foundation, Toronto.

Van der Walt, B.J., 2010a, 'The human heart rediscovered in the anthropology of D.H.Th. Vollenhoven', in B.J. van der Walt (ed.), At home in God's world, pp. 290324, The Institute for Contemporary Christianity in Africa, Potchefstroom.

Van der Walt, B.J., 2010b, 'Imaging God in the contemporary world', in B.J. van der Walt (ed.), At home in God's world, pp. 325-366, The Institute for Contemporary Christianity in Africa, Potchefstroom.

Van der Walt, B.J., 2010c, 'A new paradigm for doing Christian philosophy', in B.J. van der Walt (ed.), At home in God's world, pp. 152-182, The Institute for Contemporary Christianity in Africa, Potchefstroom.

Van der Walt, B.J., 2013a, 'Hoe om die geskiedenis van die filosofie weer te gee: 'n Verkenning van wysgerige historiografiese probleme en metodes', Tydskrif vir Geesteswetenskappe 53(1), 1-15.

Van der Walt, B.J., 2013b, 'n Skrifmatige perspektief op die geskiedenis van die westerse intellektuele denke: Die ontstaan, kontoere en vrae oor die konsekwen probleem-historiese metode', Tydskrif vir Geesteswetenskappe 53(3), 267-285.

Van der Walt, B.J., 2014a, 'Die konsep "vrou": 'n Feministiese historiografie oor die verhouding tussen die vroulike en manlike geslag', Koers - Bulletin for Christian Scholarship 79(1), Art. \#1248, 11 pages. http://dx.doi.org/10.4102/koers. Scholarship
v79i1.1248

Van der Walt, B.J., 2014b, 'Homo ludens of homo respondens? 'n Christelik-filosofiese reaksie op die hedendaagse idee van die mens as primêr' $n$ spelende in plaas van 'n antwoordende wese', Koers - Bulletin for Christian Scholarship 78(2), Art. \#63, 11 pages. http://dx.doi.org/10.4102/koers.v78i2.63

Venter, J.J., 2011, Einstein: Meetkunde en ervaring, Vraagteken, Potchefstroom.

Vollenhoven, D.H.Th., 2000, Schematische kaarten: Filosofische concepties in probleemhistorisch verband, K.A. Bril \& A.J. Boonstra (reds.), De Zaak Haes, Amsterdam.

Vollenhoven, D.H.Th., 2005a, Isagôgè philosophiae: Introduction to philosophy, J.H. Kok \& A. Tol (eds.), Dordt College Press, Sioux Center.

Vollenhoven, D.H.Th., 2005b, The problem-historical method and the history of philosophy, K.A. Bril (ed.), De Zaak Haes, Amstelveen.

Vollenhoven, D.H.Th., 2005c, Wijsgerig woordenboek, K.A. Bril (red.), De Zaak Haes, Amstelveen.

Vollenhoven, D.H.Th., 2010, Isagôgè philosophiae 1930-1945 - Tekskritische uitgave Filosofie in de traditie van de Reformatie, A. Tol (red.), V.U.-Uitgeverij, Amsterdam.

Vollenhoven, D.H.Th., 2011, Gastcolleges wijsbegeerte: Erfenis voor het heden, K.A. Bril \& R.A. Nijhoff (reds.), De Zaak Haes, Amstelveen.

Woldring, H.E.S., 2013, Een handvol filosofen: Geschiedenis van de filosofiebeoefening aan de Vrije Universiteit in Amsterdam van 1880 tot 2012, Verloren, Hilversum. 